\title{
Grade 4 children's engagements in cross-sex relationships: A case from one South African Farm School
}

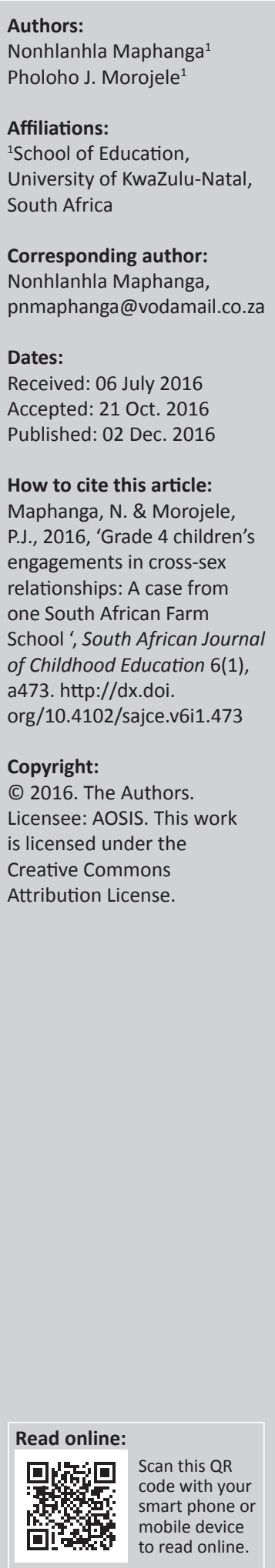

This study explores Grade 4 school children's experiences of cross-sex relationships in a coeducational farm school in uMgungundlovu district in South Africa. The aim is to understand if and how constructions of gender bear on young children's social relations at the school. Informed by children's geographies and new sociology of childhood studies, this study uses data from semi-structured interviews and photo-voice imagery based on a qualitative narrative study of three girls and three boys aged between 9 and 12 years. The study found that children's experiences of cross-sex relationships were deeply entrenched in traditional discourses of masculinities and femininities. These rigidly constructed discourses of gender were found to constrain possibilities and fluidities with which children navigated places and spaces of crosssex relationships in the school. The hegemonic regulatory power of gender norms was a yardstick, informing children's organisation and performances of cross-sex relationships even if some children had developed creative ways of subverting dominant gender norms in how they navigated in cross-sex relationships. The study argues for the liberalisation of gender norms, in order to allow children to freely - without being constrained by their genitalia - take subject positions of gender in cross-sex relationships. This would promote sustainable equitable gender relations, as children learn how to engage in cross-sex relationships, beyond the constraining prescripts of dominant masculinities and femininities.

\section{Introduction}

Cross-sex relationships are depicted as platonic prosocial interactions that endorse suppleness and sociality of deed and thought, as boys and girls actively extend their daily social engagements across gender boundaries (McDougall \& Hymel 2007). These interactions may be based on closeness, common activities, previous interactions, social behaviour and so forth. While cross-sex relationships may be distinctive in nature, there are overlapping characteristics that constitute them, viz., they mainly depend on the involvement of free, platonic desires in children's behavioural characteristics in social locations (Ellis \& Zarbatany 2007). Unlike hetero- or homosexual relationships, cross-sex relationships are normally loosely tied and with no strings attached. This means that cross-sex relationships can be initiated and dissolved with ease at any time because they are voluntary relationships which are formed by children out of their own good will. The easiness with which these relationships can be formed or dissolved, and their platonic nature, makes cross-sex relationships one of the safest and most meaningful relationships among young children. Yet, their value lies in the social connections and bonds they embrace between boys and girls based on common love, compassion and kindness, influencing positively children's sense of belongingness and emotional support (Blazek 2011).

Cross-sex relationships represent highly salient social bonds among young children in schools. Children of all age groups resort to relational friendships as a means to enhance their social wellbeing. Bisson and Levine (2009) argue that children are happier when they are with friends than when they are alone or with family members, pointing out that cross-sex relationships among school children are regarded as the most common source of childhood joy and social affinity. Within South African farm schooling contexts ravaged by a myriad of social ills, cross-sex relational friendships among children serve as 'social convoys' through school life's journey. These relationships also serve as personal and peer-based sources of socio-cultural capital, through which children navigate precarious schooling environments (Pahl 2000). From an early age, there is a very high prevalence of peer relationships between girls and boys; yet these children's relationships tend to be overlooked and devalued, especially when the preoccupation is with adult family relationship, or hetero- and homosexual relationships among the adult population (Anderson 2005). Children's cross-sex relationships are also underrepresented in the 
social scientific literature, in which the large majority of studies are on the romantic or marital ties of young adults (Sprecher \& Felmlee 2000).

Comparatively, very little is known about how platonic (nonsexual) or romantic close ties among young children bear on their schooling experiences. Young children's identities are 'informed by the explicit as well as implicit messages from our families and communities' (Bhana et al. 2007:135). There is a paucity of knowledge regarding how dominant social gender norms of femininities and masculinities, which are 'informed by the explicit as well as implicit messages' from social surroundings (Bhana et al. 2007:135), bear on children's understanding and experiences of cross-sex relationships in schools. However, Blazek and Windram-Geddes (2013) denote how children's social identities, for instance, their gender, play a critical role in the formation and dynamics of cross-sex relationships. In their active interactions of crosssex relationships, children are depicted and shaped as gendered subjects (Blazek \& Windram-Geddes 2013). This means that dominant discourses of femininities and masculinities (Epstein \& Morrell 2012) tend to determine formations and the rules by which children perform, negotiate or contest cross-sex relationships. Yet the rigidity with which dominant discourses of gender depict children's abilities and possibilities, and their promotion of inequitable gender relations, means that dominant discourses of gender may have adverse effects on the safety, social benefits and meaningfulness of the children's cross-sex relationships. For instance, pressure to conform to dominant femininities might increase girls' propensity to exploitation and other forms of violations in cross-sex relationships as they act out gender performances of relatively high expectations of their relationships involving trust and emotional intimacy (Felmlee, Sinclair \& Sweet 2012). Such affection is unfeasibly expected from boys who, to the contrary, are socialised (and even socially pressured) to perform competitive, rough and uncaring masculinities (Morojele 2011).

In this article, we examine young children's experiences of cross-sex relationships in one farm co-educational school in uMgungundlovu district in South Africa. Analysis of these experiences is made against the backdrop of dominant gender norms within the school, and the role these play in the regulation or enhancement of cross-sex relationships among the young children. We show how dominant norms of femininities and masculinities specified a range of behaviours that were deemed appropriate for particular types of crosssex relationships within a cultural backdrop of the school. Indeed, the preoccupation with dominant discourses of gender relations with hetero romanticising and normalising of cross-sex interactions (Myers \& Raymond 2010) was found to have adverse effects on non-eroticised cross-sex relationships among young children. The article also highlights the creative ways through which young children conform and subvert dominant discourses of femininities and masculinities as they actively navigate cross-sex relationships in the school. We examine the social factors that shape children's understanding of, experiences of and engagements with cross-sex relationships, and the implications of these for the social and academic well-being of the young children in this school. Against the backdrop of traditional constructions of children as innocent, immature and passive society's prospective members (Skanfors 2009; Woodhead 2008), the authors highlight the active, assertive and innovative ways through which young children played in the formation and navigation of cross-sex relationships. We contribute to the ongoing debates on children's rights to be heard and respected by foregrounding their viewpoints as meaningproducing members of society, in their own right.

\section{Social constructionism as a theoretical paradigm}

At the heart of social constructionism is the view that young children's experiences of cross-sex relationships are generated by relations, rather than by external realities (Gergen 2009). Social constructionism places emphasis on discourses and social relations as bases on which young children's experiences of cross-sex relationships are predicated (Gergen \& Gergen 2000). Gee (2011) saw discourse as a socially accepted association among ways of thinking, feeling, believing, valuing and acting that can be used to identify oneself as a member of a socially meaningful group. In this regard, this article shows how children's experiences of cross-sex relationships were intricately intertwined with dominant (and often hegemonic) constructions of gender (Ouzgane \& Morrell 2007) - what it means to be a girl or boy in that context (Morojele 2011) and the socially acceptable notions of appropriate cross-gender performances (Butler 1990). McCann \& Kim (2003) posited that a discourse is not a language or a text, but a historically, socially and institutionally specific structure of statements, terms, categories and beliefs. Indeed, the findings of this article revealed how socially instituted historical discourses of dominant femininities and masculinities played a critical role in informing the young children's imaginations, engagements and experiences of cross-sex relationships. These included discursively constituted and idealised notions of femininities and masculinities, which promoted hetero-normativity (Bhana, Nzimakwe \& Nzimakwe 2010) as the only appropriate (or at least socially acceptable) crosssex engagement. This article therefore shows how these discourses deeply suffused ways in which children experienced cross-sex relationships. Indeed, the article shows how children's active roles in cross-sex interactions mainly culminated in instances of conformities, contestations and subversions of hegemonic gender norms.

Social constructionism further believes that:

the moment we begin to articulate what there is - what is truly or objectively the case - we enter a world of discourse, and thus a tradition, a way of life and a set of value preferences. (Gergen 2009:161)

Instead of seeking facts and truths, this study focused on young children's social spaces and places within the school and how historically constituted gendered repertoires 
informed their engagements in cross-sex relationships. This theoretical paradigm enabled us to illuminate not only the social spaces and places of children's cross-sex experiences (Wyness 2003) but also how transactionality (perceived notions of personal or social beneficiation) deeply suffused children's constructions, experiences and navigation of crosssex relationships. This was especially because of the many challenges and social ills that the South African farm school context presented for these children. For instance, many children engaged in cross-sex relationships as a means of social bonding to compensate for lack of proper family care and support owing to dysfunctional families because of substance abuse and loss of one or both of their parents as a result of HIV and AIDS. While other children engaged in cross-sex relationships for protection against bullying (which was mainly inflicted by boys) or even from being reported to teachers, in cases where they had trespassed against the school rules.

\section{Conducting research with young children}

\section{Research context}

The study was conducted in a public school located in the heart of sugarcane farms in the uMgungundlovu district in KwaZulu-Natal and involved six Grade 4 children, aged between 9 and 12 years. The school is classified as a combined school, which, according to the South Africa's educational system, is a school structure where both the primary school and the secondary school learners attend in the same school, but all grouped according to their respective grades. Children in this school came from a low socio-economic background, which was mainly poverty stricken and underdeveloped. The communities, which consisted of the Basotho, Xhosa and Zulu people, followed diverse and mixed cultural beliefs and practices. Most families lived in compounds and in unplanned urbanisation, which took the form of shacks and squatter camps. Females, grandparents and children headed most households because of the HIV and AIDS pandemic in this region. Parents survived through working in the sugar cane fields and some benefited from the governmentsponsored meagre old-age pension remittances and child support grants. The school had a programme for orphans and vulnerable children, which supported learners with school uniforms, food parcels and other basic survival necessities. The infrastructure was very poor with dilapidated classrooms, broken windows, and no proper sanitation and ablution facilities. Prospects for further education beyond the school were shuttered, as most learners who had passed Grade 12 were not enrolled for further education; instead, they had recourse to sell their labour for very meagre salaries by working in the nearby farms.

\section{Research methodology}

A qualitative research paradigm was adopted as a methodological framing for the study. This paradigm was chosen for its ability to enable elicitation of quality active data, which explicates the complexities, dynamisms and emotional subjectivities of socially constituted phenomena such as real-life schooling experiences of vulnerable children (Cohen, Manion \& Morrison 2007). This allowed deeper access into the cultural contexts of the participants, and in an empowering manner that valued these children as active participants and co-constructors of knowledge about their understanding and experiences of cross-sex relationships. Unlike a quantitative research paradigm, which uses numbers and instruments (Mcmillan \& Schumacher 2010), qualitative research uses words, which privileges the children's voices. In line with the theoretical paradigm of this study, qualitative research is further concerned with the sociological nature of being and human experience (Mcmillan \& Schumacher 2010) and its appreciation of complexities, contradictions and fluidities of being, and the value of subjectivities in research adds immense richness, liveliness and dynamism to knowledge production. This approach allowed the researchers to describe and examine children's individual and common societal actions, values and perceptions (Bryman 2008) about cross-sex relationships within the immediate context in which these phenomena occurred. Through this approach, we were able to unearth complex, fluid and supple realities that informed children's understanding of the meanings, interpretations and personal experiences of cross-sex relationships. We were further able to explore deeper into the social and personal world of the participants in more interactive, relational and respectful ways. Moreover, the research participants had the opportunity to express their understanding and experiences of cross-sex relationships from their own perspectives as children, using their own words.

To further privilege children's voices, we encouraged children to tell stories (use narratives) that could depict their understandings and experiences of cross-sex relationships (Gaskell 2008). Our research instruments were designed to prompt children to narrate stories about their experiences with cross-sex relationships, instead of simply giving answers to the interview questions. For instance, our interview questions were deliberately intended to place the children where they could tell stories about their cross-sex experiences in their own way and from their own perspective, encouraging them to bring a holistic picture of the context in which the experience occurred, with the accompanying emotions about how it felt at the time of the experience. This augured well with the social context of these children where oral storytelling, in the form of fairy tales, was encouraged and is still widely practised as a part of their cultural routine. Indeed, the narratives added richness to the study by enabling children to tell stories, which were preserved in real-life memories, and therefore connected and situated in particular socio-cultural contexts of these children's schooling lives (Weed 2008).

\section{Data collection methods}

Individual and focus group semi-structured interviews and participatory photo-voice techniques were utilised 
as methods of data collection. For photo-voice, each participant was given a disposable camera with 18 frames. Pseudonyms, which the participants chose themselves, were used to name the cameras for ownership. The participants were trained on how to use the camera and were then urged to capture their chosen salient spaces and places that depict and hold meaning to their understanding and experiences of cross-sex relationships (Joubert 2012) for a period of 4 days, after which the frames were developed. The photo imagery (Figures 1-5) was then used during the individual and focus group interviews to act as ingress into the meanings, perspectives and lived experiences of these children about cross-sex relationships (Mitchell et al. 2005). Photo-voice further enabled active involvement of the participants as they took the images and helped in their analysis. This asserted the participant children as active agentic actors not only in shaping dynamics of their cross-sex engagements but also in shaping the knowledge they would like this study to produce in respect of their constructions and experiences of cross-sex relationships.

With permission from the participants, tape recorders were used to help in the accurate capturing of participant data and in supplementing data not recorded in notes. All interviews were conducted in isiZulu, which was the commonly spoken

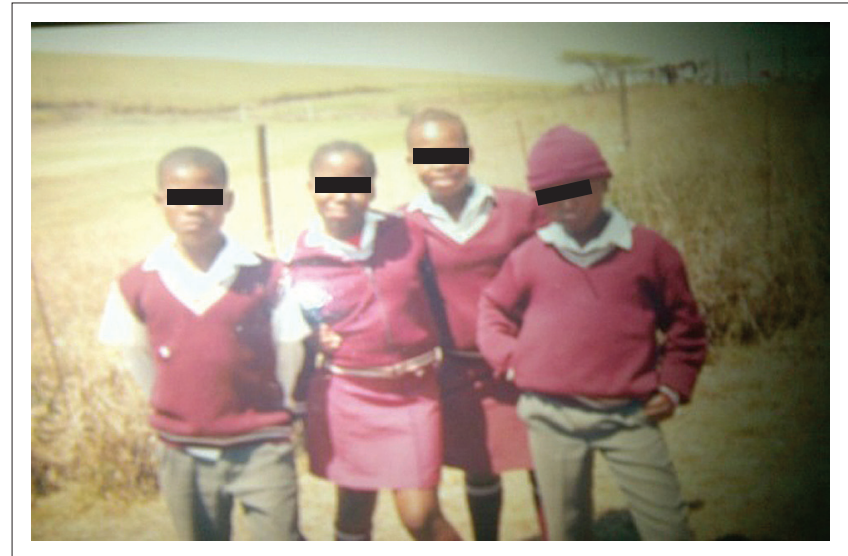

FIGURE 1: Photovoice image depicting friends of Njab - boy aged 12.

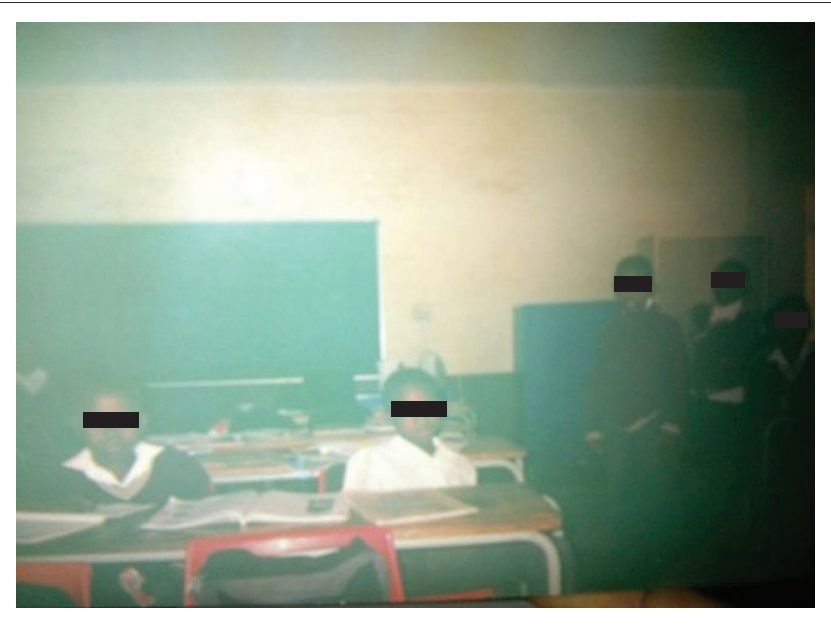

FIGURE 2: Photovoice image depicting a girl and a boy who always fought in ways that subverted dominant gender norms. language and was a vernacular of all the participants in this study. This allowed the participants to talk and express thoughts, feelings and opinions without any linguistic restrictions (Mcmillan \& Schumacher 2010). One of the authors has isiZulu as her vernacular, and thus could speak fluently with children and assisted in translating the data into English.

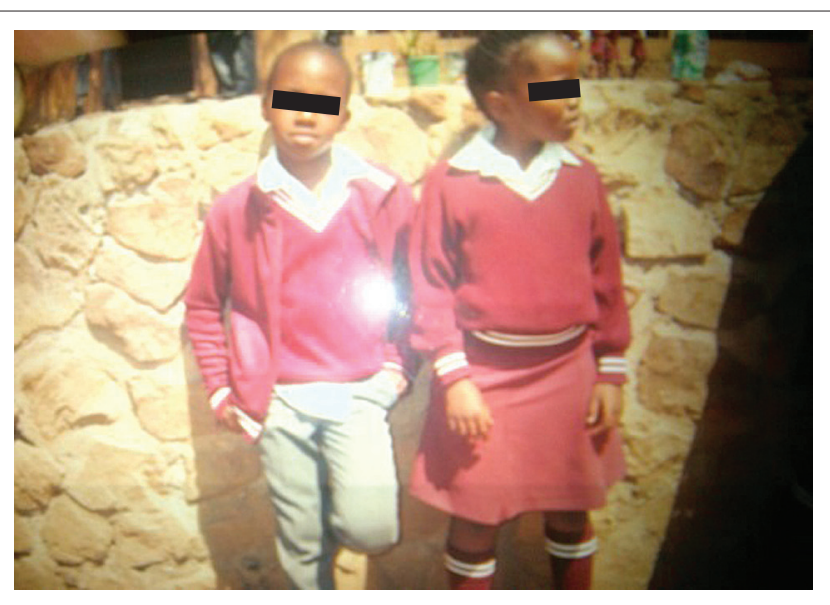

FIGURE 3: Photovoice image depicting a boy and a girl involved in cross-sex relationships.

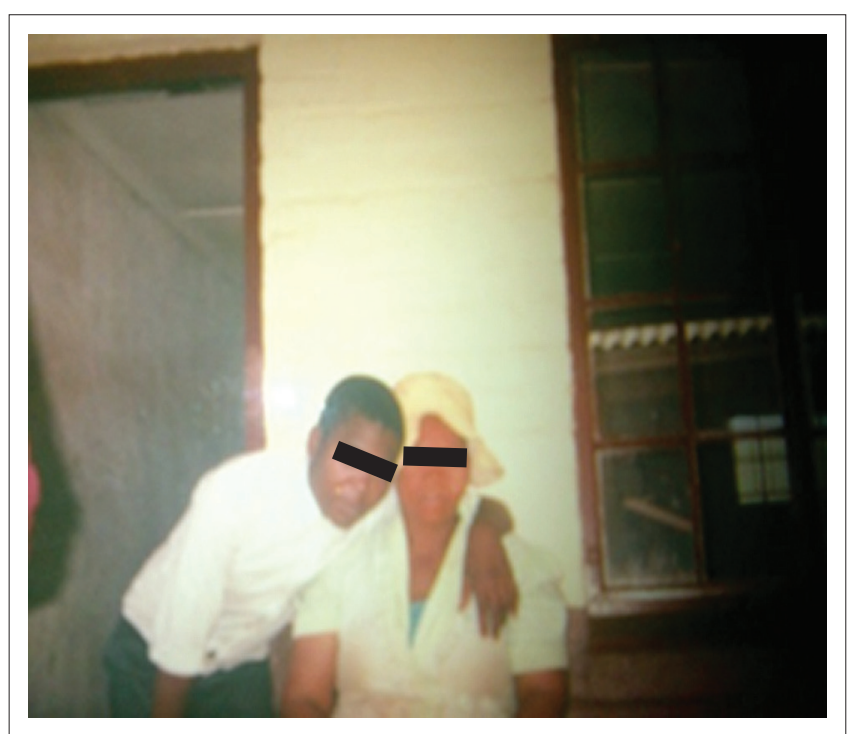

FIGURE 4: Photovoice image depicting a boy befriending a school cleaner, to deter her from reporting them to teachers.

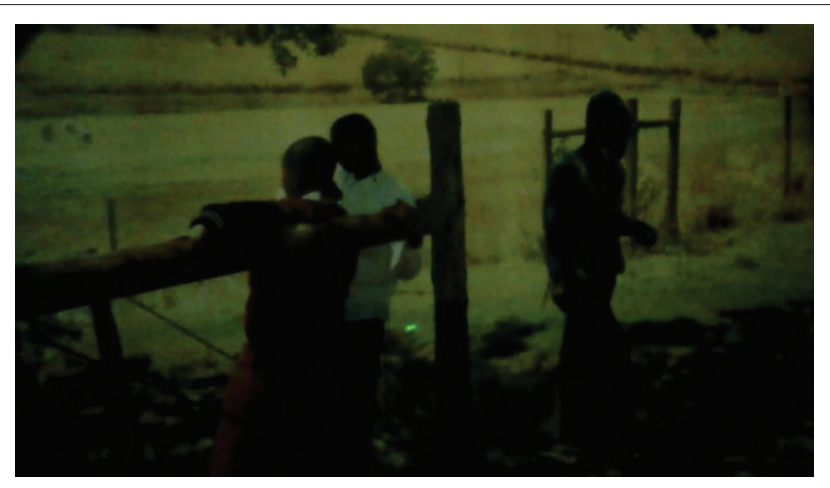

FIGURE 5: Photovoice image depicting a girl and a boy involved in heterosexua relationships. 


\section{Data analysis}

An inductive process of analysis was followed to derive patterns and themes in the data (Braun \& Clarke 2006). Listening to all the recorded data aided in the identification of the patterns and themes related to the places and spaces of cross-sex relationships in the school. This was followed by reading all the transcripts line by line for familiarity with the data and identifying sub-emerging themes related to the research question, which were then coded. The emergent themes were then coded and the pictures selected and contextualised with assistance from the participants. Careful re-listening to the recorded data was useful to ensure transcriptions' accuracy, during generation of themes and linking names of the actual informants to the pseudonyms used in this study. The participants' facial expressions and voice tone were noted in order to comprehend their emotions. The themes that emerged from all the data (photo-voice, individual and focus group interviews) were then analysed and discussed in relation to the study objectives, drawing insights from literature debates in the field, the theoretical paradigm of the study and the original critical interpretive abilities of the researchers to derive the study findings.

\section{Findings}

\section{Gendered dynamics in children's constructions of cross-sex relationships}

The findings indicate that children drew heavily on societal values of gender in their engagements in cross-sex relationships. Children's constructions of cross-sex relationships revolved around gender differences with dominant discourses of femininities and masculinities being the social rules used to legitimise formations, power hierarchies or struggles and dissolution or adaptation of cross-sex relationships. Children were regulated by some specific gender norms related to discourses of masculinity and femininity in their relationships with one another (Ní Laoire 2010). For boys, sports featured significantly as a space to exercise dominant forms of masculinities, which included being rough and displaying competitive aggression.

'When I play with them, they tell me not to be weak and not to cry easily. One day they kicked the ball too hard and I could not catch it. It hit me on the stomach and I fell down. Children who were watching laughed at me and passed bad remarks saying I will not be able compete with boys.' (Asanda, girl, 10 years)

A strong gender socialisation is indicated in the data above. Although Asanda could be seen as challenging dominant gender norms by playing football, this was met with rejection and instigation of discomfort by the boys she was playing with. The same disapproval was indicated in how Asanda claimed that children who were observing also passed denigrating remarks about her abilities to compete with boys. Yet it is not expressly clear if Asanda's intention was to engage in competitive play with the boys. There is a sense in which the socialisation of boys (in particular) predisposed boys to construct themselves in competitive terms with other boys, but once a girl gets into the picture, this shifts to competitive rivalry against a girl who should be shown that she could not outcompete boys. To some degree, cross-sex interactions in these instances were used as a basis for the appropriation of gender norms. Asanda's bravery to play football with boys is another way that could facilitate expansion of cross-sex relationships in this school beyond dominant gender norms (Rose 2007).

The laughing sarcasm and kicking the ball hard at Asanda was both a verbal and physically aggressive way in which boys displayed their disapproval of her involvement in what was regarded as a boys' sport (Marion, Buhrmester \& Underwood 2007). The dominant gender discourses that link masculinities with physical competitiveness seem to have imbued a sense of soccer ownership in boys, as if this belonged to them only (Anderson 2005; Morojele 2011). There is a likelihood that these children's tendency to regulate cross-sex relationships and other children's access to school spaces along gender lines had an adverse effect on the enhancement of the quality of children's schooling experiences. It also conforms to the traditional gender relations which promote unequal power relations between boys and girls.

The ripple effect of this is to permeate an understanding that cross-sex relationships do necessarily involve and belong to dominant categories of femininities and masculinities (Bhana et al. 2010). In which case, girls are construed as possessing characteristics of gentleness, tidiness, politeness, quietness, caring, respect and unquestioning, in sharp contrast to the characteristics of being uncaring, rough, tough, aggressive and competitive for boys. These characteristics played a major role in informing and regulating children's engagements in cross-sex relationships. In most cases, children's crosssex relationships involved expressions and contestations of dominant characteristics of boyhood and girlhood, with a particular emphasis to show differences rather than similarities between the two (Reddy 2010). The data below further indicated the children's propensities to use cross-sex relationships as avenues to display and regulate dominant feminine and masculine attributes:

Interviewer: 'Who are your friends?'

Njab (boy aged 12): 'My friends are Lindo (girl), Mbali (girl), Mpumelelo (boy) and Nipho (boy).'

Interviewer: 'How is the relationship towards each other?'

Njab: 'Our relationship towards each other is very good because we support each other if someone is sick or upset. Sometimes we fight but we still care for one another. I love playing with girls because they are very polite and caring.'

We see how Njab is comfortable to be surrounded by girls because of perceived attributes of being gentle, polite and caring. While this brought harmony in the cross-sex relationships $\mathrm{Njab}$ had with the girls, it still conforms to problematic assumptions about girls. It is not clear as to the power domination that Njab enjoyed in these relationships, but clearly, he had deeply held expectations for girls to be polite and caring to him (Healy 2011). How this was possible in the context where these relationships oscillated between 
fighting, caring for and supporting each other is a question of wonder. Nevertheless, it certainly points to the richness and dynamism with which young children's cross-sex relationships abound. Conversely, Njab challenged the dominant discourses of masculinities by engaging in platonic peer relationships with girls, for whatever the benefits he had perceived. This added to Asanda's experience above, which we argue denotes children's natural propensities to stray in non-conformity gender performances despite the rigorous social regulations against this. The findings indicate that cross-sex relationships were perfect avenues through which young children subverted dominant discourses of gender.

For some boys, cross-sex relationships were understood as a means to display dominant masculinities of being powerful, rough, tough, uncaring and showing no respect when proposing love to girls (Anderson 2005; Swain 2006), which was normally met with approval by peers as a show of real manhood (Morojele 2011). The boys who performed these were further accorded a positive social status:

Interviewer: 'You seem to be in a good mood today?'

Asanda: 'Not really, it's about what I saw yesterday on my way back home.

Interviewer: What did you see?'

Asanda: 'A boy was trying to stop a girl and the girl was afraid to talk to that boy because the girl was walking with her small brothers. The boy was angry and tried to use his power to force the girl to stop. Then one of the girl's small brothers threw a stone at the boy and one hit him on the back. The boy was furious but nothing was done because the two young brothers disappeared into the bushes. The boy went back grumbling at the girl. He grabbed her hand saying today I'm going with you. I didn't see the ending because I had to take my own path home.'

Interviewer: 'Where did the boy want to take the girl?'

Asanda: 'The boy wanted to take her to his home. The girl was refusing that is why she chose to walk with her small brothers. Other boys at the back were passing remarks encouraging the boy to continue with what he was doing.'

Interviewer: 'Is that a good thing?'

Asanda: 'No, but that boy is so rude. He treats girls so badly. He is not afraid of doing evil things.'

In attempts to conform to dominant discourses of boys as uncaring and rough, it appears that some boys used this to engage in coercive cross-sex relationships with girls. Issues of hierarchical power relations of gender and age are illustrated above. The girls' younger brothers could do nothing beyond throwing stones and disappearing into the bush in fear of a brutal response from the coercive cross-sex relationship maker. It is not clear how the girl ultimately responded to the situation, but research (Morojele 2011, for instance) has found cases where such an abusive boy gets a real beating to his very dismay (also see below for further illustration of this). However, it is possible that such an incident could end in physical and sexual violence, including rape, especially if this were to continue unabated with the support (instead of rebuke) of observers, as it was in the case above.
The following excerpt illustrates how from time to time girls subverted dominant gender norms, as well as the boys' reaction to this:

Njab: 'This boy and a girl are friends but they always fight. When we were saying riddles in class, his friend made a bad riddle about her. We all laughed. Weh! Zan (girl) was furious and she kicked him very hard. Then they started to fight.'

Qini (a boy aged 11): 'I was so surprised to see a girl fighting so strong. Other boys were telling the boy to kick Zan on the stomach, but it was too late because the boy was bleeding. All the class looked at them.'

Njab: 'If, I were him I would have hurt her with a chair. Girls should not defeat boys because if seen, the boys would be described as weak and of no use. Other boys would even scold you.'

Boys did not entertain girls who displayed what was regarded as masculine behaviour. It was said that Zan's relationships were characterised by fights, but boys who liked fighting were never labelled as such. What is revealing about the above scenario is that some girls (in particular Zan) did not perceive themselves as weak and fragile despite the dominant rhetorical portrayal of girls as such. Zan's mastery of the fighting skill created panic among the boys as they tried to coach the boy on how to win the fight but to no avail. The shaming and ridicule of the boy, who was defeated by a girl, denote the pressure that boys who could not uphold hegemonic performances of gender had to endure. From this narration, we learn the paradoxical nature of the dominant constructions of gender. Whereas these gender values are thought to give social power and ascendancy of boys over girls, the cost of upholding these beliefs can sometimes be very high for boys. Socially in genuine circumstances, some boys simply cannot uphold these. Such is the self-perpetuating and self-fulfilling nature of hegemonic discourses of gender which, in the bigger scheme of things, relegate and compromise the quality of schooling experiences of both boys and girls.

Conversely, boys who displayed caring and empathy towards girls were depicted as weak and they were laughed at, teased and called by disgusting names.

Nale (boy aged 11): '(Pointing) these two are involved in something. When I asked them what is happening between them they just ignore me. The boy always buys nice things for her.'

Sbu (boy aged 12): 'intervening, No!no!no! I will not spend my money with girls. Girls always want this and that, but he likes to hang around with girls. I do not want to be ruled by girls.'

Interviewer: 'Is it wrong when boys buy nice things for girls?'

Nale: 'It is not wrong if you buy some goodies for the person you like if you can afford. Come on Sbu are you not jealous.'

The data denotes contestations between Sbu and Nale regarding boys buying 'goodies' for the girls they are involved with in cross-sex relationships. Part of the dominant expression of masculinities is to support the females who are regarded as weak and unable to support themselves. So buying 'goodies' for females is part and parcel of the 
masculine scheme of power expression and domination over females, which supposedly informed Nale's positive attitude towards the show of affection by the boy in the cross-sex relationship depicted above. The power underpinning of this conversation was indicated when Sbu associated being kind and caring towards girls to being ruled by girls, which he expressly disliked, whereas Sbu's agitation indicates a possibility that the very same masculine display of buying 'goodies' for females is simultaneously constructed as wary and undesirably the things that girls expect from boys. So this gives way for boys to denigrate females as nagging want(ing) this and that, as Sbu claimed, so that the vicious cycle of masculine power domination over femininities could be completed.

\section{Gender dynamics in children's experiences of cross-sex relationships}

Children's experiences of cross-sex relationships were based on things done together among girls and boys, like playing, walking, sitting, sharing etc. Conflicts among children in these relationships were triggered by disputes, as there were many unique and overlapping dynamics in the construction and keeping of cross-sex relationships. To sustain those relationships called for the involvement of desirable behavioural characteristics and social positioning. Children's cross-sex experiences culminated in three categories, namely: personal involvement, things observed and things heard, involving harmony, tensions and exclusions:

'We are four in our group, two girls and two boys. I sit with Fezeka (a girl). Lindo and Bheka (boys) sit at the back desk. When it was Life Orientation period, Lindo the boy at the back of me drew a picture of a girl with plaited hair and he hanged it on the wall near him. Everybody was laughing in class except Fezeka and me. When I turned my head, I saw everybody staring at me. Fezeka (whispering), 'look at the picture on the wall'. When I looked at it, it was a picture of a woman with a baby on her back trying to stop a car with my name written at the bottom. I screamed and tore the paper to pieces. I was so angry with him the whole day. After school he bought me a fat cake, I wanted to refuse it but I was hungry so I took it.' (Naledi, girl, 12 years)

Life Orientation is a period where children find time in Arts and Crafts to put what is in their minds down on the paper or to pour their emotions into a symbolic form. The image that the boy drew about Naledi was very confusing and indeed made her very unhappy. It is not clear what this could have been meant to symbolise or express, but a woman with a baby on her back stopping a car does resemble experiences of many young females in this rural area. Whatever the intentions were, the bottom line is, this was a denigrating imagination of Naledi, which conformed to menial constructions of girls and females, in general. The question of boys using 'goodies', as indicated above, to pacify girls is also exemplified, and how girls' inability to buy themselves a fat cake became a sure way to win Naledi back from her furious reaction to the boy. This is one example that depicts the transactional of children's negotiation of cross-sex relationships.
Findings also denoted how children constituted their crosssex relationships based on what they had observed in their communities. A lot could be learnt about children's communities and home background based on how they engaged in their experiences with cross-sex relationships.

Interviewer: 'Tell me more about your friends.'

Qiniso: 'Hahaha (laughing). We have all been friends since Grade R. We come from the same area. All our big sisters and brothers are in the same school with us. I play lot of games with them. Our special game is "ugxa" hopscotch. We share our food during break time ... [pause] but Zanele shouts a lot and she tried to control us most of the time.'

Interviewer: 'Why did Zanele shout at you?'

Qiniso: 'Hmm, Zanele shouts at us for no reason. She behaves like the bully boys. She is like her mother who shouts at her father when he is drunk. Her parents always fight during fortnight pay days. Her father took all his money and spent it in alcohol with the shebeen women. He comes home drunk with no money and with no food. Zanele's mother shouts at him, they exchange vulgar and her mother beats him. Zanele is not afraid of anyone in the class. It is nice to be around her because nobody messes with her. She can fight too.'

While fighting boys by a girl might be regarded as regressing gender norms, the findings indicate how social dynamics of poverty and male (father's) recklessness render men in despicable and embarrassing situations. The reliance of Zanele's mother on her husband who spends his meagre salary at a sheeben has made Zanele adapt her cross-sex relationships in ways that challenge the myths of rough and physically strong boys and caring, meek and physically weak girls. It is important to note that Zanele was seemingly a bully to boys - and as Oiniso implied, very caring and protective even to boys, just as her mother was supposedly bully and physically abusive to her father, because he did not perform his socially expected duty to support his family financially. In this case, the abuse was not self-initiated but a response to some form of abuse (careless neglect of family) already perpetuated by the father and therefore, by means of observation, Zanele (as a child) learnt the skill of fighting and being bully to boys. The fact that she was caring and protective to other girls like Oiniso denotes that Zanele's behaviour was not a self-initiated propensity to violence, but a reaction against abusive and bullying boys in the school. This scored Zanele more friendships with girls who could not fight boys, as they saw their relationship with her as an investment in protection against abusive boys.

Young children's experiences of cross-sex relationships were also drawn from observing children (especially older children in the school) engaging in heterosexual romantic relationships. It was immediately clear as to what precipitated children's platonic cross-sex relationships into heterosexual romantic intimacy. Perhaps it could be boys' performances of dominant masculinities to exercise power over girls, with a view to invade girls' privacy and access sexual benefits. On the contrary, it could be as a result of the role played by dominant constructions of girls as expecting and demanding more intimacy and emotional closeness in their relationships 
with boys (Felmlee et al. 2012). What was clear though was the fact that when girls and boys who escalated into sexual romantic relationships were caught, this was regarded more of a girls' problem than the boy's. For instance, such girls were labelled as the ones who were after boys or loving boys too much, and thus being ridiculed, shamed and scolded more than boys.

The data revealed that boys had developed a creative strategy of dealing with the female cleaning staff (who were the ones likely to find them in compromising spaces with girls) when they were caught with girls. Perhaps this might have been another reason why the odds of rebuke and shaming were always skewed against girls in the event their cross-sex romantic relationships were discovered:

Sbu (boy): 'This is Lizwi [older boy in the school] and aunt Lolo who is cleaning our school premises.'

Interviewer: 'Tell me more about your experiences with her.'

Sbu: 'Aunt Lolo tells the students and the teachers that, she is tired of seeing group of big boys and girls drinking alcohol and smoking in the toilets and behind the classrooms. Now boys are trying to make good relationships with aunt Lolo [meant to discourage her from reporting them to teachers] so that they won't get to trouble. One day I heard aunt Lolo warning a girl who was kissing and hugging her boyfriend after school in front of her. She said "oh! My girl tomorrow it will be you who will witness what you are doing as a sign of disrespect towards adults."'

The data illustrate far more nuanced relationships that the cleaning staff had with children in the school, and because of the low social position the cleaning staff occupied in the school context, it appears that boys and girls were free to kiss and hug in their presence. Although the cleaner (aunt Lolo) regarded this as a sign of disrespect for adults, nonetheless it gave her a rare opportunity to witness children's heterosexual encounters. We argue that the spinoffs for adults (including teachers and parents) of having the opportunity to witness and engage in children's romantic relationships far outweigh the risks of encouraging children to do these in places where no adult could see them.

Another issue is boys' formation of seemingly transactional cross-sex friendships with the cleaning staff to discourage them from reporting cases of boy's heterosexual encounters with girls. It is interesting how it was easier for boys than girls to form such relationships with the female cleaning staff. Perhaps this could have been as a result of the general acceptance for boys to engage in heterosexual relationships with girls, while at the same time girls were simultaneously discouraged to engage in these relationships. Hence, the reason why, even when these were discovered, girls, and not boys, were scolded ridiculed and shamed. This is a bleak example of how the moral panics of children's engagement in sexual relationships (Bhana et al. 2010) and gender power relationships militated against girls in this school.

The home, society, school and elder peers played a critical role in socialising younger boys to perform cross-sex relationships in conformity to dominant norms of masculinities as a proof of 'real manhood' (Lorber 2010; Ouzgane \& Morrell 2007). Proposing love to girls at school and having many heterosexual girlfriends were admired at the school, as a display of 'real manhood' for boys. The findings denote how this show of 'real manhood' sometimes culminated in teenage pregnancy, with the girl child being adversely and inequitably militated against:

Sbusiso: 'My brother is in a relationship with a girl. They walk together in the afternoons, sit together in the back seats of the bus. Sometimes they meet at night but we watch them. One day I tried to sit with them but his friends chased me away saying, "ifunani lentwana lapha" meaning what is this young boy doing here? I looked at my brother for help but nothing was done except that he accompanied me to the front seats.'

Interviewer: 'Why did they chase you away from the back seats?'

Sbusiso: 'One Saturday morning when I woke up I saw two mothers and Bongi my brother's girlfriend talking very soft with my mother. When I looked at Bongi, she was crying. My mother asked me to call my brother. After a long talk, they left. Mother was very furious; she passed strong words to my brother. "You have to look for a job to support your baby my boy, I have taken care of you and your young brother all by myself, but you decided to sleep around with girls. This is what I get in return. I am sick and tired of you and girls". Other children at school told me that Bongi is pregnant and Sizwe is the father.'

The pressure for boys to have sexual girlfriends might have precipitated Sizwe's involvement in these relationships. Obviously, this attracted some respect and high social standing among peers in the school (Skelton 2001). Being unable to have a romantic relationship was not accepted and it attracted ridicule and laughter, as this showed no proof of real manhood. The consequence was a pregnant Bongi whose parents Sibusiso witnessed visiting his parents to lay a complaint against Sizwe (Bongi's known boyfriend). The devastating economic and social consequences that being pregnant relegated the schoolgirls in this rural and povertystricken context cannot be overstated. This evokes the early argument we made about the need for adults (teachers, parents and guardians inclusive) to actively engage young children in conversations about cross-sex relationships, including romantic homo- and heterosexual interactions.

The dominant reluctance to engage young children, which is normally based on moral panics and fears of associating sex and childhood, only serves to perpetuate the inequitable gender social order. More and more young schoolgirls fall pregnant and their life opportunities diminished by economic deprivation and social rejection they experience in response to their pregnancy. Therefore, we have a choice to make - to either maintain a false view, which disassociates children and sexual activity, and have more lives ruined to HIV and AIDS or have girls' educational opportunities being shattered. This overemphasises the long overdue need for adults to engage young children in conversations about sex and educate them about sexual health and so forth, as well as about the implications of sexual choices on their lives. 


\section{Ethical consideration}

Consent for the research was sought from the Department of Education in the district and the principal of the school. Ethical clearance was then sought from the research office at the University of KwaZulu-Natal. Permission was also obtained from the parents or guardians of the participants and the participants themselves. We respected the notion that children are human beings who have to be given a choice to take decisions on matters concerning their lives (Christensen \& Prout 2002). During the study, participants' rights and welfare were protected and pseudonyms were used to protect their identity. All parties were assured of anonymity and confidentiality, and the participants were further informed that participation is voluntary and they could withdraw from the study at any time if they desire (Cohen, Manion \& Morrison 2007).

\section{Conclusion, discussions and recommendations}

Transactionality and gender featured prominently as matrixes around which young children's cross-sex relationships were constructed, experienced and navigated. Almost all cross-sex relationships that children formed were made on a perceived notion of some benefits to be derived from such a relationship, whether it was social bonding, assistance with school, protection against bullying boys, protection against being reported to teachers and so forth. Dominant discourses of femininities and masculinities pervaded almost all spheres of children's engagements with cross-sex relationships. Children's active roles in these relationships involved insistences of conformities, contestations and subversions of hegemonic gender norms. The resultant power imbalances enshrined in hegemonic discourses of gender gave rise to conflicts, affirmations, praise, pride, disgruntlements, ridiculing, shame and so forth as some boys and girls either struggled to uphold or deliberately performed cross-sex relationships in ways that did not affirm these dominant constructions of gender. Whether boys and girls upheld or toppled dominant discourses of gender, the all-embracing consequential compromising that dominant discourses of gender imposed on the quality of children's cross-sex relationships, and their lives in general, was evident. Boys' feelings of lack of 'real manhood' which attracted ridicule and shaming among peers, girls' being subjected to menial and subservient position in these relationships, which included falling pregnant, all pointed to the challenges that both girls and boys had to endure.

Further research is required to provide more empirical data on how platonic cross-sex relationships among young children could be used as a productive resource for promoting and encouraging alternative constructions of gender as fluid and multiple attributes of human beings. At this impressionable age, children need to be socialised and encouraged to engage in healthy, prosocial and gender equitable cross-sex relationships. This would further enhance children's strategies to use cross-sex relationships to navigate some of the social ills they experienced because of their farm school context ravaged by poverty and HIV and AIDS, as indicated above. We need to devise strategies on how to quip teachers, parents and guardians with the necessary skills, knowledge and personal as well as professional dispositions (Van Laren et al. 2016), to enable their active and meaningful involvement in conversations with children about healthy and gender equitable cross-sex relationships. The aim should be to make schools gender egalitarian spaces, where children engage in cross-sex relationships in ways that enhance their social identities and are afforded the opportunity to develop to their maximum human potential, regardless of their gender or sexual inclinations.

\section{Acknowledgements}

The authors wish to acknowledge, parents, guardians and teachers for allowing their children to participate in this study, as well as children for their active participation, and willingness to share their experiences.

\section{Competing interest}

The authors declare that they have no financial or personal relationship(s) that may have inappropriately influenced them in writing this article.

\section{Authors' contribution}

N.M. formulated the research problems, questions, methods, conducted data collection, transcription and translation, as well as some preliminary data analysis and interpretation under close supervision by the second author. P.J.M. conceptualised and undertook the writing of this article.

\section{References}

Anderson, E., 2005, 'Orthodox and inclusive masculinity: Competing masculinities among heterosexual men in a feminized terrain', Sociological Perspectives 48(3), 337-355. http://dx.doi.org/10.1525/sop.2005.48.3.337

Bhana, D., Morrell, R., Hearn, J. \& Moletsane, R., 2007, 'Power and identity: An introduction to sexualities in Southern Africa', Sexualities 10(2), 131-139. http:// dx.doi.org/10.1177/1363460707075794

Bhana, D., Nzimakwe, T. \& Nzimakwe, P., 2010, 'Gender in the early years: Boys and girls in an African working class primary school', Educational Development 31 443-448. http://dx.doi.org/10.1016/j.ijedudev2010.09.001

Bisson, M.A. \& Levine, T.R., 2009, 'Negotiating friends with benefits relationship', Archives of Sexual Behavior 38(1), 66-73. http://dx.doi.org/10.1007/s10508-0079211-2

Blazek, M., 2011, 'Place, children's friendships, and the formation of gender identities in a Slovak urban neighbourhood', Children's Geographies 9, 285-302. http://dx. doi.org/10.1080/14733285.2011.590700

Blazek, M. \& Windram-Geddes, M., 2013, 'Editorial: Thinking and doing children's emotional geographies', Emotion, Space and Society 9, 1-3. http://dx.doi. org/10.1016/j.emospa.2013.07.006

Braun, V. \& Clarke, V., 2006, 'Using thematic analysis in psychology', Qualitative Research in Psychology 3(2), 77-101. http://dx.doi.org/10.1191/1478088706qp063oa

Bryman, A., 2008, Social research methods, 3rd edn., Oxford University Press, New York.

Butler, J., 1990, Gender trouble and the subversion of identity, Routledge, New York.

Christensen, P. \& Prout, A., 2002, 'Working with ethical symmetry in social research with children', Childhood 9(4), 477-497. http://dx.doi.org/10.1177/0907568202009004007

Cohen, L., Manion, L. \& Morrison, K., 2007, Research methods in education, 6th edn., New Routledge Falmer, New York.

Ellis, W. \& Zarbatany, L., 2007, 'Explaining friendship formation and friendship stability: The role of children and friends' aggression and victimization', MerrillPalmer Quarterly 53(1), 79-104. 
Epstein, D. \& Morrell, R., 2012, 'Approaching Southern theory: Explorations of gende in South African', Education, Gender, and Education 24(5), 469-482. http://dx.doi. org/10.1080/09540253.2012.711036

Felmlee, D., Sinclair, C. \& Sweet, E., 2012, 'Gender rules: Same and cross-gender friendship norms', Sex Roles 66(8), 518-529. http://dx.doi.org/10.1007/s11199011-0109-z

Gaskell, C., 2008, 'Isolation and distress? (Re) thinking the place of emotions in youth research', Children's Geographies 6(2), 169-181. http://dx.doi.org/10.1080/ 14733280801963128

Gee, J.P., 2011, An introduction to discourse analysis: Theory and methods, 3rd edn., Routledge, New York.

Gergen, K.J., 2009, An invitation to social constructionism, Sage, London.

Gergen, M.M. \& Gergen, K.J., 2000, 'Qualitative inquiry: Tensions and transformations', in N.K. Denzin and Y.S. Lincoln (eds.), Handbook of qualitative research, pp. 10251046, Sage, London.

Healy, M., 2011, 'Should we take the friendships of children seriously?', Mora Education 40(4), 441-456. http://dx.doi.org/10.1080/03057240.2011.618774

Joubert, I., 2012, 'Children as photographers: Life experiences and the right to be listened to', South African Journal of Education 32(4), 449-464. http://dx.doi. org/10.15700/saje.v32n4a677

Lorber, D., 2010, Gender inequality: Feminist theories and politics, 4th edn., Oxford University, New York.

Marion, K., Buhrmester, D. \& Underwood, M., 2007, 'Friendship features and social exclusion: An observational study examining gender social context', Special Issue: Gender and Friendships 53(3), 412-438.

McCann, C.R. \& Kim, S., 2003, Feminist theory reader, Routledge, New York.

McDougall, P. \& Hymel, S., 2007, 'Same-gender versus cross-gender friendships conceptions', Merrill-Palmer Quarterly 53(3), 347-380. http://dx.doi.org/10.1353/ mpq.2007.0018

Mcmillan, J.H. \& Schumacher, S., 2010, Research in education. Evidence based inquiry, 7th edn., Pearson, Upper Saddle River, NJ.

Mitchell, C., Moletsane, R., Stuart, J., Buthelezi, T. \& de Lange, N., 2005, 'Taking pictures/taking action!' Visual methodologies in working with young people', Children First 9(60), 27-30.

Morojele, P., 2011, 'What does it mean to be a boy? Implications for girl's and boy's schooling experiences in Lesotho rural schools', Gender and Education 23(6), 677-693. http://dx.doi.org/10.1080/09540253.2010.527828
Myers, K. \& Raymond, L., 2010, 'Elementary school girls and heteronormativity: The girl project', Gender \& Society 24(2), 167-188. http://dx.doi.org/10.1177/ girl project', Gender

Ní Laoire, C., 2010, 'Girls just like to be friends with people', Children Geographies 9(4) 303-318. http://dx.doi.org/10.1080/14733285.2011.590713

Ouzgane, L. \& Morrell, R., 2007, African Masculinities: Men in Africa from the late nineteenth century to the present, Taylor \& Francis, New York.

Pahl, R., 2000, On friendship, Blackwell Publishing, Oxford.

Reddy, S., 2010, 'Shifting public/private boundaries: Young women's sexuality within the context of HIV and AIDS in South Africa', Agenda 24(83), 88-94.

Rose, J., 2007, 'Structure, content and socio-emotional correlates of girls' and boys' friendships', Merrill-Palmer Quarterly 53(3), 489-506. http://dx.doi.org/10.1353/ mpq.2007.0019

Skanfors, L., 2009, 'Ethics in child research: Children's agency and researchers' ethical radar', Childhoods Today 3(1), 1-22.

Skelton, C., 2001, Schooling in boys: Masculinities and primary education, Open University, Buckingham.

Sprecher, S. \& Felmlee, D, 2000, 'Romantic partners' perceptions of social network attributes with the passage of time and relationship transitions', Personal Relationships 7(4), 325-340. http://dx.doi.org/10.1111/j.1475-6811. 2000.tb00020.x

Swain, J., 2006, 'Reflections on patterns of masculinity in school settings', Men and Masculinities 8(3), 331-349. http://dx.doi.org/10.1177/1097184X05282203

van Laren, L., Volks, C., Pithouse-Morgan, K. \& Alves, S., 2016, 'Scrapbooking as a tool for transdisciplinary professional learning about HID and AIDS curriculum integration in higher education', South African Journal of Higher Education 30(4), 74-93.

Weed, M., 2008, 'A potential method for the interpretative synthesis of qualitative research: Issues in the development of meta- interpretation', Internationa Journal for Social Research Methodology 11(1), 13-28. http://dx.doi.org/10. 1080/13645570701401222

Woodhead, M., 2008, 'Childhood studies: Present and future', in M. Kehily (ed.), An introduction to childhood studies, pp. 17-34, Open University, Maidenhead.

Wyness, M., 2003, 'Children's space and interests: Constructing an agenda for students' voice', Children's Geographies 1(2), 223-239. http://dx.doi.org/10.1080/ 14733280302193 